\title{
Oral immunotherapy in clinical practice
}

\author{
Stefania Arasi, Lucia Caminiti, Giuseppe Crisafulli, Giovanni B Pajno* \\ From 71st Congress of the Italian Society of Pediatrics. Joint National Meeting SIP, SIMGePeD, Study Group \\ on Pediatric Ultrasound, SUP Study Group on Hypertension \\ Rome, Italy. 4-6 June 2015
}

\section{Introduction}

Food avoidance is still considered the gold-standard treatment for food allergy (FA). However, recently it has been consolidating the theory that, where possible, the food intake might facilitate the induction of desensitization and tolerance, resulting more effective and safer -if we consider the possibility of accidental ingestion- than a strict avoidance diet [1].

Furthermore, specific oral immunotherapy (OIT) is the unique active treatment for IgE-mediated FAs [1].

\section{Efficacy}

Studies have shown short-term efficacy: namely theOITability to induce desensitization (loss of responsiveness to food-antigen during continuous assumption of OITdoses) [2-5]. Conversely, data are still insufficient and controversial regarding long-term efficacy: namely, the achievementof tolerance(configured when the offending food is removed from the diet and, if reintroduced, does not elicit any adversereaction) [2-5].

Recent data have shown that a key role in the induction of tolerance by OIT is played by a subgroup of regulatory $\mathrm{T}$ cells known as "induced T reg" (iTreg) [6,7]. Epigenetic studies in vivo assessthatOIT determines hypomethylation of FOXP3 protein in specific antigeniTreg only in individuals tolerant. Therefore, changes in the DNA of iTreg - specific antigen may predict the development of a state of clinical immune tolerance during OIT [8].

\section{Safety}

About safety, allergic reactions occurred in the majority of patients treated. They are primarily mild reactions, severe in about $4 \%$; however, no threatening-life events nor death has been reported [9]. Frequency and severity

\footnotetext{
* Correspondence: giovanni.pajno@unime.it

Department of Pediatrics-Allergy Unit, University of Messina, Messina, 98121, Italy
}

gradual dose increases [1].

Careful clinical monitoring by qualified personnel in a medical environment is essential. Consequently, OIT costs are high.

In all immunotherapy treatments, safety is of paramount importance. Therefore, when severe adverse reactions occur, OIT should be stopped and revaluated.

\section{Possible approches improving OIT}

Several efforts have been made to perfect OIT: e.g.antigens with reduced allergenicity and adjuvants inducing faster immune responses of "protection". Particularly promising is OIT associated with omalizumab, anti-IgE antibody, resulting safe and able to accelerate the desensitization compared to traditional protocols [10-12].

\section{Conclusions}

Further researches are needed in order to verify the degree of long-term safety as well as the long-term efficacy of OIT.

Given the interest and the celerity of development of this field of research in the recent years, we are confident in the near achievement of a personalized treatment, planned, safe and effective, to be used in clinical practice.

\section{Published: 30 September 2015}

References

Pajno GB, Nadeau KC, Passalacqua G, Caminiti L, Hobson B, Jay DC, et al: The evolution of allergen and non-specific immunotherapy: past achievements, current applications and future outlook. Expert Rev Clin Immunol 2015, 11:141-54

2. Shekelle P, Maglione M, Riedl M, et al: Food Allergy: Evidence Report., Accessed at http://www.rand.org/health/centers/epc/.

3. Chafen JJ, Newberry SJ, Riedl MA, Bravata DM, Maglione M, Suttorp MJ, et al: Diagnosing and Managing Common Food Allergies: A Systematic Review. JAMA 2010, 303:1848-1856.

Calvani M, Giorgio V, Miceli Sopo S: Specific oral tolerance induction for food. A systematic review. Eur Ann Allergy Clin Immunol 2010, 42:11-19. 
5. Fisher HR, du Toit G, Lack G: Specific oral tolerance induction in food allergic children: is oral desensitisation more effective than allergen avoidance? A meta-analysis of published RCTs. Arch Dis Child 2011, 96:259-264.

6. Soyer O U, Akdis M, Ring J, Behrendt $H$, Crameri R, Lauener R, et al: Mechanisms of peripheral tolerance to allergens. Allergy 2013, 68:161-170.

7. Pajno GB, Cox L, Caminiti L, Ramistella V, Crisafulli G: Oral Immunotherapy for Treatment of Immunoglobulin E-Mediated Food Allergy: The Transition to Clinical Practice. Pediatr Allergy Immunol Pulmonol 2014 27:42-50.

8. Syed A, Garcia MA, Lyu SC, Bucayu R, Kohli A, Ishida S, et al: Peanut oral immunotherapy results in increased antigen-induced regulatory $\mathrm{T}$-cell function and hypomethylation of forkhead box protein 3 (FOXP3). J Allergy Immunology 2014, 10:1.

9. Kim EH, Burks W: Managing food allergy in childhood. Curr Opin Pediatr 2012, 24:615-20.

10. Nadeau KC, Schneider LC, Hoyte L, Borras I, Umetsu DT: Rapid oral desensitization in combination with omalizumab therapy in patients with cow's milk allergy. J Allergy Clin Immunol 2011, 127:1622-4.

11. Schneider LC, Rachid R, Lebovidge J, Blood E, Mittal M, Umetsu DT: A pilot study of omalizumab to facilitate rapid oral desensitization in high-risk peanut-allergic patients. J Allergy Clin Immunol 2013, 132:1368-1374.

12. Bégin $P$, Dominguez $T$, Wilson $S P$, Bacal $L$, Mehrotra A, Kausch B, et al: Phase 1 results of safety and tolerability in a rush oral immunotherapy protocol to multiple foods using Omalizumab. Allergy Asthma Clin Immunol 2014, 10:7.

\section{Submit your next manuscript to BioMed Central} and take full advantage of:

- Convenient online submission

- Thorough peer review

- No space constraints or color figure charges

- Immediate publication on acceptance

- Inclusion in PubMed, CAS, Scopus and Google Scholar

- Research which is freely available for redistribution

Submit your manuscript at www.biomedcentral.com/submit
Biomed Central 